\title{
Research Article \\ EVALUATION AND CHARACTERIZATION OF SOME RARE AND MEDICINALLY IMPORTANT CURCUMA SPECIES IN TERAI REGION OF WEST BENGAL
}

\author{
DEB B.C. ${ }^{1}$, CHAKRABORTY S. ${ }^{* 2}$, DEBNATH M.K. ${ }^{3}$ AND ROY M.K. ${ }^{4}$ \\ 1,2Department of Genetics and Plant Breeding, Uttar Banga Krishi Vishwavidyalaya, Cooch Behar, 736165, West Bengal, India \\ 3Department of Agricultural Statistics, Uttar Banga Krishi Vishwavidyalaya, Cooch Behar, 736165, West Bengal, India \\ 4Plant Pathology, AICRP on Spices, Uttar Banga Krishi Vishwavidyalaya, Cooch Behar, 736165, West Bengal, India \\ *Corresponding Author: Email - soumendra1@gmail.com
}

Received: June 01, 2018; Revised: June 07, 2018; Accepted: June 08, 2018; Published: June 30, 2018

\begin{abstract}
Seven genotypes of mango turmeric and two genotypes of blue turmeric were taken for the investigation in order to find out the suitability of cultivating these medicinally enriched genotypes in the terrain region of West Bengal. Standard package of practices was adopted for developing the genotypes in this region. Characterization, which is mandatory for conservation of germplasms was done according to the DUS descriptors ic developed by Indian Institute of Spices Research. Randomized blocked design was adopted for evaluation and characterization of mango ginger and blue turmeric where MG-6 was found to have highest yield per plot, MG-8 was found to have highest rhizome wt, MG-4 was found to have highest number of mother rhizome, MG-1 highest rhizome length in quantitative estimations of rhizome and qualitative estimation of each genotype was done for characterization to evaluate the performances of all the gen otypes in this region.
\end{abstract}

Keywords- Mango ginger, blue turmeric, quantitative characterization, qualitative characterization, DUS characters

Citation: Deb B.C., et al., (2018) Evaluation and Characterization of Some Rare and Medicinally Important Curcuma Species in Terai region of West Bengal. International Journal of Microbiology Research, ISSN: 0975-5276 \& E-ISSN: 0975-9174, Volume 10, Issue 6, pp.-1244-1251.

Copyright: Copyright@2018 Deb B.C.,et al., This is an open-access article distributed under the terms of the Creative Commons Attribution License, which permits unrestricted use, distribution and reproduction in any medium, provided the original author and source are credited.

\section{Introduction}

Turmeric (Curcuma) is an herbaceous perennial plant [1] belongs to the KingdomPlantae, Order- Zingiverales, genus- Curcuma, family zingiberaceae. This genus consists of approximately 70 species [2]. Turmeric has been distributed in India, south-east Asian countries and north Australia. Indian Institute of Spices Research (IISR), Calicut, collects and conserves turmeric germplasm by both in-situ and exsitu conservation. Till date, the National Germplasm Repository of Spices at IISR maintains more than 700 accessions of turmeric, including land races, improved varieties, open pollinated progenies (OP), related species and taxa [3]. The origin of Turmeric is in South-East Asia [4]. Curcuma longa L. is the most common and important plant among the species of Curcuma reported and studied till date. Turmeric is known as the "Golden spice" as well as the "Spice of life" [5]. The highest diversity is concentrated in India and Thailand, with at least 40 species in each area, followed by Burma, Bangladesh, Indonesia and Vietnam [6]. The genus curcuma was named by Linnaeus (1753) [7]. The generic epithet is derived from the Arabic word karkum, meaning yellow, referring to the yellow color of the rhizome, and Curcuma is the latinized version $[8,9]$. This curcuma genus is mainly distributed in south and southeast Asia [5]. The first chromosome number of turmeric was reported by Suguira, (1931) and Suguira, (1936) $[10,11]$ as $2 n=$ 64. The other reports of somatic chromosome number of curcuma spp. are $2 n=42$ for $C$. amada Roxb $2 n=42$ for $C$ aromatic Salisb, $2 n=62$, for $C$. longa $L$. [12] and $2 n=64$ for C. zedoariaa and C. petiolata [13]. Sharma and Bhattacharyya, (1959) [14] reported $2 n=42$ in curcuma amada and $2 n=62$ in Curcuma longa. Chakravorti, (1948) [15] further reported C. longa $L .(2 n=62,63,64)$. Unusual deviations such as $2 n=32$ [16], $2 n=48$ [17], $2 n=62$ [12], [14], $2 n=64$ [15] and $2 n=84$ [18] have also been reported in turmeric. Turmeric is a sterile auto-triploid $(2 n=63)$ crop with no viable seeds. This is one of the major bottlenecks in crop improvement of turmeric [19]. The basic chromosome number of the genus Curcuma is suggested as $x=21$ which in turn originated by dibasic amphidiploidy from $x=9$ and $x=12$ or by secondary polyploidy [20-22]. Characterization is one of the most important steps for conservation of valuable and rare genotypes of blue turmeric and mango ginger in the Curcuma family.

\section{Objectives of the investigation}

Quantitative characterization of all the genotypes of 7 numbers of Mango ginger and 2 number of Blue turmeric germplasms which are distantly related genotypes from turmeric will be investigated according to PPV \& FR (IISR) in both plant and rhizome characters. Qualitative characterization of all the genotypes of 7 numbers of Mango ginger and 2 number of Blue turmeric germplasms which are distantly related genotypes from turmeric will be investigated according to PPV \& FR (IISR) in both plant and rhizome characters.

\section{Materials and methods \\ Experimental site}

The present investigation was conducted during the summer season of 2014-2015 and 2015- 2016 at the University Farm of Uttar Banga Krishi Viswavidyalaya, Pundibari, Cooch Behar. The farm is situated at $26^{\circ} 19^{\prime} 86^{\prime \prime} \mathrm{N}$ latitude, $89^{\circ} 23^{\prime} 53^{\prime \prime}$ $\mathrm{E}$ longitude with an altitude of $43 \mathrm{~m}$ above the mean sea level. The experimental site falls under sub Himalayan Terai agro-climatic condition. The average annual rainfall is $3000 \mathrm{~mm}$ and most of which is received during June to September. The temperature begins to rise from the end of February reaching maximum towards the July-August. The relative humidity remains high throughout the year [Table-1]. Total experimental area was divided into unit plots of $3 \mathrm{~m} \times 1 \mathrm{~m}$ size according to the need for each experiment to accommodate all the treatments each having three replications. Channel of $40 \mathrm{~cm}$ width demarcated each replication and each plot was separated by 0.25 meter width furrow. A fertilizer dose of $\mathrm{N}: \mathrm{P}_{2} \mathrm{O}_{5}: \mathrm{K}_{2} \mathrm{O} @$ 120:60:60 (Kg/ha) were given for conventional plot. 
Table-1 Chromosome numbers of some economically important species of Curcuma

\begin{tabular}{|l|l|l|}
\hline \multicolumn{1}{|c|}{ Species } & \multicolumn{1}{c|}{ Chromosome number } & \multicolumn{1}{c|}{ Reference } \\
\hline C. amada & $2 n=42$ & {$[12,14,15,21]$} \\
\hline C. angustifolia & $2 n=42,2 n=64$ & {$[14,15]$} \\
\hline C. aromatica & $2 n=42,2 n=63,2 n=86$ & {$[12,15,21]$} \\
\hline C. decipiens & $2 n=422 n=32$ & {$[12]$} \\
\hline C. longa & $2 n=62$ & {$[12,14]$} \\
\hline & $2 n=62,63,64$ & {$[15]$} \\
\hline & $2 n=63$ & {$[21]$} \\
\hline & $2 n=64$ & {$[11]$} \\
\hline C. neilgherrensis & $2 n=42$ & {$[21]$} \\
\hline C. petiolata & $2 n=64$ & {$[12]$} \\
\hline C. zedoaria & $2 n=63$ & {$[21]$} \\
\hline & $2 n=63,64$ & {$[15]$} \\
\hline C. caesia, C. haritha & $2 n=42$ & \\
\hline C. malabarica & $2 n=63$ & \\
\hline C. raktakanta & $2 n=63$ & {$[38]$} \\
\hline C. aeruginosa & $2 n=63$ & \\
\hline
\end{tabular}

Table-2 Origin and chromosome number of turmeric and turmeric related species

\begin{tabular}{|c|c|c|c|}
\hline Species & $2 n$ & Origin & Reference \\
\hline \multirow[t]{6}{*}{ C. amada Roxb } & 42 & India & [12] \\
\hline & 42 & India & [15] \\
\hline & 42 & India & [14] \\
\hline & 42 & India & [21] \\
\hline & 40 & India & {$[17]$} \\
\hline & 42 & Bangladesh & [39] \\
\hline \multirow{8}{*}{$\begin{array}{l}\text { C. aromatica } \\
\text { Salisb. }\end{array}$} & 42 & India & {$[12]$} \\
\hline & 42 & India & [15] \\
\hline & 63,86 & India & [21] \\
\hline & 84 & India & [22] \\
\hline & 63 & China & [40] \\
\hline & 42 & India & [41] \\
\hline & 63 & Thailand & [42] \\
\hline & 63 & Bangladesh & [39] \\
\hline \multirow[t]{3}{*}{ C. caesia Roxb. } & 22 & India & [17] \\
\hline & 63 & India & [38] \\
\hline & 63 & Bangladesh & [39] \\
\hline \multirow[t]{11}{*}{ C. longa L. } & 64 & Unknown & {$[10,11]$} \\
\hline & 62 & India & [12] \\
\hline & 62,63 & India & [15] \\
\hline & 32 & Unknown & {$[16]$} \\
\hline & 62,93 & India & [14] \\
\hline & 63 & India & [21] \\
\hline & 63 & Indonesia & {$[43,44]$} \\
\hline & 48 & India & [17] \\
\hline & 63 & Thailand & [42] \\
\hline & 63 & Bangladesh & [39] \\
\hline & 48 & India & [45] \\
\hline
\end{tabular}

The required amount of fertilizer was calculated on the basis of plot size and applied as Urea $(46 \% \mathrm{~N})$, SSP $\left(16 \% \mathrm{P}_{2} \mathrm{O}_{5}\right)$ and MOP $\left(60 \% \mathrm{~K}_{2} \mathrm{O}\right)$. The total amount of Phosphorus and Potassium was applied as basal and the Nitrogen was applied in three equal split doses, i.e., at 45, 75 and 110 days. Then fully decomposed Farm Yard Manure incorporated thoroughly to the experimental plots @ 15 tha for both conventional and organic plot at 10 days before planting. Healthy finger and mother rhizomes of all germplasms with well-developed buds were used for planting after proper sorting. Completely dried rhizomes were started planting from May, 2014 and 2015 with spacing of $30 \mathrm{~cm}$ between the rows at a depth of $4.5 \mathrm{~cm}$.

\section{Table of Turmeric plants characteristics}

The test Guidelines developed by Indian Institute of Spices Research, Calicut was finalized by the Task Force (2007) constituted by PPV \& FR Authority [23]. Statistical analysis was performed on the mean values of each character was compared for each replication and then used for statistical analysis. The Design of experiment was randomized block design.

\section{Analysis of Randomize Block Design}

$\mathrm{RCBD}$ was done in all the genotypes of blue turmeric and mango ginger was done in GEN-RES software for statistical analysis. In analysis of variance significant or non-significant results can be ascertained by observing the comparison of calculated value with the tabulated value.

Table-3 Meteorological parameter of the location during the experiment 2014-2016

\begin{tabular}{|c|c|c|c|c|c|}
\hline \multirow[t]{2}{*}{ Month } & \multirow[t]{2}{*}{ Rainfall } & \multicolumn{2}{|c|}{$\begin{array}{l}\text { Temperature } \\
\left({ }^{\circ} \mathrm{C}\right)\end{array}$} & \multicolumn{2}{|c|}{$\begin{array}{l}\text { Relative } \\
\text { Humidity(\%) }\end{array}$} \\
\hline & & Max & Min & Max & Min \\
\hline Apr-14 & 8.7 & 31.4 & 22.5 & 76.4 & 71.2 \\
\hline May-14 & 10.06 & 32.1 & 22.6 & 78.2 & 72.1 \\
\hline Jun-14 & 20.1 & 32.5 & 24.9 & 88.8 & 81.5 \\
\hline Jul-14 & 9.6 & 33.4 & 26 & 84.4 & 79.4 \\
\hline Aug-14 & 14.6 & 31.6 & 25.4 & 89.1 & 85.9 \\
\hline Sep-14 & 12.7 & 31.6 & 24.3 & 89.8 & 86.3 \\
\hline Oct-14 & 0.7 & 31.7 & 20.8 & 81.9 & 84.4 \\
\hline Nov-14 & 0 & 29.7 & 16.1 & 87.2 & 85.3 \\
\hline Dec-14 & 0 & 25.7 & 11 & 88.5 & 85.8 \\
\hline Jan-15 & 23.1 & 24.1 & 10.2 & 90.3 & 78.2 \\
\hline Feb-15 & 15.5 & 26.6 & 11.6 & 84.3 & 69.1 \\
\hline Mar-15 & 0.2 & 30.1 & 16.8 & 73.7 & 55.9 \\
\hline Apr-15 & 120.2 & 30.4 & 19.4 & 76.4 & 62.7 \\
\hline May-15 & 377.8 & 31.8 & 22.3 & 84.6 & 76.6 \\
\hline Jun-15 & 622 & 31.2 & 23.9 & 91.4 & 82.9 \\
\hline Jul-15 & 296.9 & 33.4 & 25.1 & 84.5 & 75 \\
\hline Aug-15 & 25.7 & 31.8 & 25.2 & 88.9 & 81.1 \\
\hline Sep-15 & 10 & 32.9 & 24.9 & 78.5 & 71.6 \\
\hline Oct-15 & 0 & 32.6 & 22.3 & 72.6 & 67.7 \\
\hline Nov-15 & 0 & 29.3 & 22.7 & 81.7 & 74.9 \\
\hline Dec-15 & 0 & 25.1 & 18.2 & 83.3 & 79.3 \\
\hline Jan-16 & 0 & 23.5 & 9.7 & 89 & 81.2 \\
\hline Feb-16 & 0 & 27.5 & 12.8 & 81.4 & 69 \\
\hline Mar-16 & 0 & 30.7 & 17.2 & 70.2 & 59.5 \\
\hline
\end{tabular}

Source: Integrated Agro-met Advisory Senvice Unit: Pundibari (UBKV, Pundibari)

$\begin{aligned} & \text { Table-4 List of Germplasms of Sooty, mango ginger and blue turmeric } \\
& \begin{array}{r}\text { Mango Ginger } \\
\text { (Curcuma amada Roxb.) }\end{array}\end{aligned}$
\begin{tabular}{|l|l|l|l|} 
(Curcuma caesia Roxb.) \\
\hline SN & Germplasm & SN & Germplasm \\
\hline 1 & MG-1 & 1 & BT-162 \\
\hline 2 & MG-4 & 2 & BT-183 \\
\hline 3 & MG-5 & & \\
\hline 4 & MG-6 & & \\
\hline 5 & MG-7 & & \\
\hline 6 & MG-8 & & \\
\hline 7 & MG-9 & & \\
\hline
\end{tabular}

Table- 5 IC numbers of mango ginger and blue turmeric

\begin{tabular}{|c|c|c|c|c|}
\hline \multicolumn{2}{|c|}{ Mango Ginger } & \multicolumn{3}{|c|}{ Blue turmeric } \\
\hline 1 & MG-1 & IC-0615273 & BT-162 & IC-0615270 \\
\hline 2 & MG-4 & IC-0615274 & BT-183 & IC-0615272 \\
\hline 3 & MG-5 & IC-0615275 & & \\
\hline 4 & MG-6 & IC-0615276 & \\
\hline 5 & MG-7 & IC-0615277 & \\
\hline 6 & MG-8 & IC-0615278 & \\
\hline 7 & MG-9 & IC-0615279 & \\
\hline
\end{tabular}

\section{Results and discussion}

Seven germplasms of Mango ginger (Curcuma amada Roxb) along with two germplasms of Blue turmeric (Curcuma caesia Roxb.) were characterized in accordance with DUS testing procedure as described in the "Protection of Plant Varieties And Farmers' Rights Authority" (PPV\&FRA, 2007) Indian Institute of Spices Research (IISR) Govt. of India. 


\section{Plant Height (cm)}

In the Pooled data analysis, the plant height was found to be varied from $141.7 \mathrm{~cm}$ (MG-5) to $85.1 \mathrm{~cm}$ (MG-8) [Table-8]. The overall mean value of 9 germplasms of Blue-turmeric and Mango-ginger plant height was $118.4 \mathrm{~cm}$. Here no any germplasm was found as at par with the highest MG-5 $(141.7 \mathrm{~cm})$ and lowest MG$8(85.1 \mathrm{~cm})$ germplasm so the others were significantly differed from the highest and lowest value [Table-8]. In 2005 [24] used plant height character of the characterization of different germplasm of turmeric. In the study of [25] used the plant height character for differentiating the different turmeric germplasms.

\section{Number of Shoots}

The number of shoots per clump in pooled data of 2014-2015 and 2015-2016 was found to be varied from 5.0 (BT-183) to 1.5 (MG-8) [Table-8]. The mean performance of the 9 germplasms of blue-turmeric and mango-ginger was 3.1. Here only one germplasm MG-4(4.5) was statistically at par with the highest number of shoots par plant BT-183 (5.0) and germplasm MG-9 (1.7) was statistically at par with the lowest number of shoots par plant MG-8(1.5). Others were significantly differed from the highest as well as the lowest value [Table-8]. [26] characterized 100 accessions of ginger germplasm based on morphological, yield, and quality parameters. Moderate variability was observed for many yield and quality traits. Tiller number per plant had the highest variability, followed by rhizome yield/plant. Padmadevi, et al., (2012) [27] results obtained that the growth characters of turmeric with respect to different parameters such as number of tillers was observed.

Number of Leaves per plant: Number of leaves on the main shoot in the pooled data analysis was varied from 11.2 (MG-4) to 9.2 (MG-9) [Table-8]. The mean value of this parameter was 10.1 . Here no any statistically at par germplasms were found with the heights and lowest number of leaves per plant [Table-8]. Xiao, et al., (2004) [28] studied on histological and morphological difference in the leaves of Curcuma in China. The optical microscope and electronic microscopic scanning were used to characterize the leaves of Curcuma.

Petiole Length $(\mathrm{cm})$ : The Petiole length $(\mathrm{cm})$ of pooled data 2014-2015 and 2015-2016 was found to be varied from $35.7 \mathrm{~cm}$ (BT-183) to $14.3 \mathrm{~cm}$ (MG-9) [Table-8]. Mean value of this Petiole length was $25.3 \mathrm{~cm}$. Here no any germplasm was found statistically at par with the highest and lowest petiole length [Table-8]. [6] used plant quantitative character like leaf petiole length $(\mathrm{cm})$ for the characterization of 20 turmeric germplasms.

Lamina Length $(\mathrm{cm})$ : The value of lamina length of pooled data analysis was found to be varied from $61.8 \mathrm{~cm}$ (MG-4) to $52.0 \mathrm{~cm}$ (MG-6) and the mean value was 51.0cm [Table-8]. BT-183 $(56.9 \mathrm{~cm})$, MG-1 $(57.7 \mathrm{~cm})$ and MG-5 $(58.6 \mathrm{~cm})$ were statistically at par with the highest MG-4 $(61.8 \mathrm{~cm})$ and germplasms like MG$7(84.8 \mathrm{~cm})$, MG-8 $(39.5 \mathrm{~cm})$, MG-9 $(43.2 \mathrm{~cm})$ and BT-162 $(40.7 \mathrm{~cm})$ were statistically at par with the lowest lamina length MG-6 $(52.0 \mathrm{~cm})$ and others were significantly differed [Table-8]. [29] take leaf length character of turmeric plant for their study on character association and path analysis for yield components. These characters are also suggested by [30]. According to [31], [17], [32], [29] and [33] the wet rhizome yield is direct effect by phenotypic character of leaf length.

Lamina Width $(\mathrm{cm})$ : Lamina width of pooled data analysis was found to be varied from $17.3 \mathrm{~cm}$ (MG-4) to $11.6 \mathrm{~cm}$ (MG-8) [Table-8]. The mean value of Lamina width was $13.5 \mathrm{~cm}$. Here no any germplasm was found statistically at par with the highest lamina width MG-4 $(17.3 \mathrm{~cm})$. Only two germplasms BT-162 $(11.7 \mathrm{~cm})$ and MG-6 $(12.0 \mathrm{~cm})$ were statistically at par with the lowest lamina width MG-8 $(11.6 \mathrm{~cm})$ and others were significantly differed from the highest and lowest lamina width [Table-8]. Tomar, et al., (2005) [29] took leaf breadth character of turmeric plant for their study on character association and path analysis for yield components. These characters are also suggested by Singh \& Chaudhary, (1977) [30]. Hikmat, et al., (2012) [6] used plant quantitative character like leaf width for the characterization of 20 turmeric germplasms. Rao A Manohar, et al., (2005) [24] used leaf breadth $(\mathrm{cm})$ character for the characterization of different germplasm of turmeric. Bandyopadhyay, et al., (2002) [25] used the length of leaf breadth for differentiate the different turmeric germplasms in intercropped with arecanut.

Plant Diameter $(\mathrm{cm})$ : Plant diameter from the pooled data analysis was found to be varied from $10.4 \mathrm{~cm}$ (MG-4) to $5.7 \mathrm{~cm}$ (MG-8) [Table-8]. The mean value of plant diameter was $8.0 \mathrm{~cm}$. BT-183 $(10 \mathrm{~cm})$ and MG-7 $(9.3 \mathrm{~cm})$ were statistically at par germplasms with the highest plant height MG-4(10.4) and only MG-9 $(6.0 \mathrm{~cm})$ was statistically at par with the lowest plant diameter MG-8(5.7cm). All other the germplasms were significantly differed from the highest and lowest plant diameter [Table-8]. Chandra, et al., (1999) [34] studied the performance of twenty-five turmeric genotypes of Meghalaya region with the help of stem diameter. Padmadevi, et al., (2012) [27] found on their study on the effect of different grades of rhizomes on growth and yield of turmeric, that the growth characters of turmeric with respect to the parameter such as stem girth.

Primary rhizome length $(\mathrm{cm})$ : The length of primary rhizome of the pooled data analysis from the year 2014-2015 and 2015-2016 was found to be varied from $11.9 \mathrm{~cm}$ (MG-1) to $7.4 \mathrm{~cm}$ (MG-9) [Table-8]. Mean value was $9.3 \mathrm{~cm}$. Here no any Germplasm was found statistically at par with the highest primary rhizome length MG-1 $(11.9 \mathrm{~cm})$ and only one germplasm MG-7 $(8.3 \mathrm{~cm})$ was statistically at par with the lowest of primary rhizome length MG-9 $(7.4 \mathrm{~cm})$ and others were significantly differed from the highest and lowest length of primary rhizome [Table-8]. Sunita, et al., (2014) [35] in their work they take the rhizome characters like length of finger after harvesting and cleaned of the soil particles. According to Dash, et al., (2014) [36] the rhizome length of the rhizome was significantly varied among the germplasm. The significant differences were found among the germplasm in respect of the length of rhizome.

Number of mother rhizome: Number of mother rhizome from the pooled data was found to be varied from 1.7 (BT-162 and MG-4) to 1.0 (MG-1, MG-6 and MG7) [Table-8]. The mean was 1.3. Germplasms BT-183(1.5), MG-9(1.3), MG-5(1.3) and MG-8(1.5) were statistically at par with highest number of mother rhizome BT162 and MG-4 (1.7). Only MG-9(1.3) was statistically at par with the lowest number of mother rhizome MG-1, MG-6 and MG-7 (1.0) [Table-8]

Rhizome Internode Pattern $(\mathrm{cm})$ : The distance between internode of from the pooled data of 2014-2015 and 2015-2016 was found to be varied from $1.8 \mathrm{~cm}$ (MG-1) to $1.0 \mathrm{~cm}$ (MG-7 and MG-9) [Table-8]. Mean of the parameter was found 1.3. Here no any germplasm was found statistically at par with the highest MG-1 $(1.8 \mathrm{~cm})$ and lowest MG-7 and MG-9 $(1.0 \mathrm{~cm})$ length of internode, so all others were significantly differed from the lowest and highest value of internode pattern [Table-8]. Chandra, et al., (1999) [34] studied the performance of twenty-five turmeric genotypes of Meghalaya region with the help of internodal distance of primary finger rhizome.

Single rhizome weight: The weight of single rhizome in the pooled data analysis was found to be varied from $455.6 \mathrm{~g}$ (MG-8) to $149.4 \mathrm{~g}$ (MG-7) [Table-8]. The mean value was $307.7 \mathrm{~g}$. BT-183(436.3GM) and (MG-1(446.5GM) germplasms were found statistically at par with the highest number or single rhizome weight germplasm MG-8(455.6g) but no germplasm was found statistically at par with the lowest number of single rhizome weight germplasm MG-7(149.4g) so all other germplasms were significantly differed from the highest and lowest value of single rhizome weight [Table-8]. According to [37] concluded that the highest genotypic coefficient of variation was found in initial weight of rhizome, and wet rhizome yield per plant and this result is also supported by Hazra, et al., (2000) [32].

\section{Characterization \\ Pseudo stem habit}

In the characterization of pseudo stem habit from the pooled data of two years of two years of 9 germplasms, it was found that 2 numbers of germplasms were under 'Compact' group namely MG-5 and MG-9 (Table: 9). In 'Open" group namely MG-1, MG-6, MG-6, MG-7, MG-4, MG-8, BT-162 and BT-183 germplasms were found [Table-9]. 
Evaluation and Characterization of Some Rare and Medicinally Important Curcuma Species in Terai region of West Bengal

\begin{tabular}{|c|c|c|c|c|}
\hline SN & Characters & States & Stage of observation & Type of assessment \\
\hline \multirow[t]{2}{*}{1} & \multirow[t]{2}{*}{ Plant: Pseudo stem habit } & Compact & \multirow[t]{2}{*}{150 days of sowing } & \multirow[t]{2}{*}{ VG } \\
\hline & & Open & & \\
\hline \multirow[t]{3}{*}{2} & \multirow[t]{3}{*}{ Plant: Height (cm) } & Short $(<85)$ & \multirow[t]{3}{*}{150 days of sowing } & \multirow[t]{3}{*}{ MS } \\
\hline & & Medium (85-100) & & \\
\hline & & Tall $(>100)$ & & \\
\hline \multirow[t]{3}{*}{3} & \multirow[t]{3}{*}{ Plant: Number of shoots } & Few $(<3)$ & \multirow[t]{3}{*}{150 days of sowing } & \multirow[t]{3}{*}{ MG } \\
\hline & & Medium (3-5) & & \\
\hline & & Many $(>5)$ & & \\
\hline \multirow[t]{3}{*}{4} & \multirow{3}{*}{$\begin{array}{l}\text { Plant: Number of leaves on } \\
\text { main shoot }\end{array}$} & Few $(<5)$ & \multirow[t]{3}{*}{150 days of sowing } & \multirow[t]{3}{*}{ MG } \\
\hline & & Inter mediate $(5-10)$ & & \\
\hline & & Many $(>10)$ & & \\
\hline \multirow[t]{3}{*}{5} & \multirow[t]{3}{*}{ Plant: Leaf disposition } & Erect $\left(<45^{\circ}\right)$ & \multirow[t]{3}{*}{150 days of sowing } & \multirow[t]{3}{*}{ VG } \\
\hline & & Semi-erect $\left(45-85^{\circ}\right)$ & & \\
\hline & & Horizontal $\left(>85^{\circ}\right)$ & & \\
\hline \multirow[t]{3}{*}{6} & \multirow[t]{3}{*}{ Leaf: Petiole length (cm) } & Short $(<15)$ & \multirow[t]{3}{*}{150 days of sowing } & \multirow[t]{3}{*}{ MS } \\
\hline & & Inter mediate (15-25) & & \\
\hline & & Long (>25) & & \\
\hline \multirow[t]{3}{*}{7} & \multirow[t]{3}{*}{ Leaf: Lamina length (cm) } & Short $(<30)$ & \multirow[t]{3}{*}{150 days of sowing } & \multirow[t]{3}{*}{ MS } \\
\hline & & Medium (30-40) & & \\
\hline & & Long (>40) & & \\
\hline \multirow[t]{3}{*}{8} & \multirow[t]{3}{*}{ Leaf: Lamina width (cm) } & Narrow $(<10)$ & \multirow[t]{3}{*}{150 days of sowing } & \multirow[t]{3}{*}{ MS } \\
\hline & & Medium (10-15) & & \\
\hline & & Broad (>15) & & \\
\hline \multirow[t]{2}{*}{9} & Leaf: Venation & Close & 150 days of & VG \\
\hline & pattern & Distant & sowing & \\
\hline 10 & Leaf: Margin & Even & 150 days of & VG \\
\hline & & Wavy & sowing & \\
\hline
\end{tabular}

Categorization of the genotypes: Bavappa et al, 2007

MG : Measurement by a single observation of a group of plants or parts of plants ; MS : Measurement of a number of individual plants or parts of plants VG : Visual assessment by a single observation of a group of plants or parts of plants; VS : Visual assessment by observations of individual plants or parts of plants

Table-7: Turmeric plants characteristics according to PPV \&FRA act

\begin{tabular}{|c|c|c|c|c|}
\hline SN & Characters & States & Stage of observation & Type of assessment \\
\hline \multirow[t]{3}{*}{1} & \multirow[t]{3}{*}{ Rhizome: Habit } & Compact & \multirow[t]{3}{*}{ At harvest } & \multirow[t]{3}{*}{ VG } \\
\hline & & Intermediate & & \\
\hline & & Loose & & \\
\hline \multirow[t]{2}{*}{2} & \multirow[t]{2}{*}{ Rhizome: Shape } & Straight & \multirow[t]{2}{*}{ At harvest } & \multirow[t]{2}{*}{ VG } \\
\hline & & Curved & & \\
\hline \multirow[t]{3}{*}{3} & \multirow{3}{*}{$\begin{array}{l}\text { Primary Rhizome } \\
\text { Length }(\mathrm{cm})\end{array}$} & Short $(<5 \mathrm{~cm})$ & \multirow[t]{3}{*}{ At harvest } & \multirow[t]{3}{*}{ MS } \\
\hline & & Medium (5 - $10 \mathrm{~cm})$ & & \\
\hline & & Long $(>10 \mathrm{~cm})$ & & \\
\hline \multirow[t]{2}{*}{4} & \multirow{2}{*}{$\begin{array}{l}\text { Rhizome: Internode } \\
\text { pattern } \\
(\mathrm{cm})\end{array}$} & Close $(<1)$ & \multirow[t]{2}{*}{ At harvest } & \multirow[t]{2}{*}{ MS } \\
\hline & & Distant $(>1)$ & & \\
\hline \multirow[t]{2}{*}{5} & \multirow{2}{*}{$\begin{array}{l}\text { Rhizome: Status of tertiary } \\
\text { rhizome }\end{array}$} & Absent & \multirow[t]{2}{*}{ At harvest } & \multirow[t]{2}{*}{ VG } \\
\hline & & Present & & \\
\hline \multirow[t]{3}{*}{6} & \multirow[t]{3}{*}{ Rhizome: Inner core colour } & Orange & \multirow[t]{3}{*}{ At harvest } & \multirow[t]{3}{*}{ VS } \\
\hline & & Lemon Yellow & & \\
\hline & & Radish Yellow & & \\
\hline \multirow[t]{3}{*}{7} & \multirow[t]{3}{*}{ Dry recovery (\%) } & Low $(<15)$ & \multirow{3}{*}{$\begin{array}{l}\text { After harvest } \\
\text { And curing }\end{array}$} & \multirow[t]{3}{*}{ MG } \\
\hline & & Intermediate (15-20) & & \\
\hline & & High $(>20)$ & & \\
\hline
\end{tabular}

MG : Measurement by a single observation of a group of plants or parts of plants; MS : Measurement of a number of individual plants or parts of plants VG : Visual assessment by a single observation of a group of plants or parts of plants; VS : Visual assessment by observations of individual plants or parts of plants Categorization of the genotypes: Bavappa et al, 2007

Plant Height: In the characterization of plant height from the pooled data of two years of 9 germplasms, it was found that 7 numbers of germplasms were under 'Tall' group MG-1, MG-5, MG-6, MG-7, MG-4, BT-162 and BT-183 (Table: 4.15.1). In 'Medium' group MG-9 and MG-8germplasm was found [Table-9].

Leaf disposition: In the characterization of leaf disposition from the pooled data of two years of 9 germplasms, it was found that 6 numbers of germplasms were under 'Erect' group MG-5, MG-9, MG-1, MG-7, MG-4 and BT-162. In 'semi-erect'
MG-6, MG-8 and BT-183 [Table-9].

\section{Petiole length}

In the characterization of petiole length from the pooled data of two years of 9 germplasms, it was found that1numbers of germplasms was under 'Short' group MG-9. In 'Inter mediate' group MG-1 and MG-8 germplasms were found [Table9]. In 'Long' group MG-5, MG-4, MG-6, MG-7, BT-162 and BT-183 germplasm were found [Table-9]. 
Table-8 Year wise and pooled data analysis of plant characters of Blue turmeric (Curcuma caesia Roxb) and Mango Ginger (Curcuma amada Roxb).

\begin{tabular}{|c|c|c|c|c|c|c|c|c|c|c|c|c|c|}
\hline S & Germplas & \multicolumn{3}{|c|}{ Plant height (Mean) } & \multicolumn{3}{|c|}{ Number of leaves (Mean) } & \multicolumn{3}{|c|}{ No. of Shoots (Mean) } & \multicolumn{3}{|c|}{ Petiole Length (Mean) } \\
\hline $\mathrm{N}$ & $\mathrm{ms}$ & 2015 & 2016 & Pooled & 2015 & 2016 & Pooled & 2015 & \multicolumn{2}{|r|}{ Pooled } & 2015 & 2016 & Pooled \\
\hline 1 & BT-162 & 108.7 & 116.3 & 112.5 & 10.3 & 10.3 & 10.3 & 3.3 & \multicolumn{2}{|l|}{2.7} & 29.8 & 34.4 & 32.1 \\
\hline 2 & BT-183 & 131.5 & 130.6 & 131.0 & 9.7 & 9.3 & 9.5 & 5.7 & \multicolumn{2}{|l|}{4.3} & 34.5 & 36.8 & 35.7 \\
\hline 1 & MG-01 & 134.0 & 130.3 & 132.1 & 10.3 & 10.0 & 10.2 & 3.7 & \multicolumn{2}{|l|}{3.0} & 20.1 & 22.0 & 21.1 \\
\hline 2 & MG-05 & 140.2 & 143.1 & 141.7 & 9.3 & 9.7 & 9.5 & 2.7 & \multicolumn{2}{|l|}{2.7} & 24.6 & 26.5 & 25.5 \\
\hline 3 & MG-06 & 111.0 & 108.9 & 110.0 & 11.3 & 10.0 & 10.7 & 3.7 & \multicolumn{2}{|l|}{3.0} & 29.1 & 28.5 & 28.8 \\
\hline 4 & MG-07 & 117.8 & 117.3 & 117.6 & 11.7 & 9.7 & 10.7 & 2.7 & \multicolumn{2}{|l|}{2.3} & 27.1 & 28.2 & 27.7 \\
\hline 5 & MG-4 & 139.2 & 137.7 & 138.5 & 11.7 & 10.7 & 11.2 & 4.7 & \multicolumn{2}{|l|}{4.3} & 26.2 & 26.6 & 26.4 \\
\hline 6 & MG-8 & 86.5 & 83.6 & 85.1 & 10.0 & 9.3 & 9.7 & 1.7 & \multicolumn{2}{|l|}{1.3} & 14.9 & 17.0 & 15.9 \\
\hline 7 & MG-9 & 97.7 & 96.1 & 96.9 & 8.7 & 9.7 & 9.2 & 1.7 & 1.7 & 1.7 & 12.0 & 16.7 & 14.3 \\
\hline & Range & $\begin{array}{c}140.2- \\
86.5\end{array}$ & $\begin{array}{c}143.1- \\
83.6\end{array}$ & $\begin{array}{c}141.7- \\
85.1\end{array}$ & $11.7-8.7$ & $\begin{array}{c}10.7- \\
9.3\end{array}$ & $11.2-9.2$ & $5.7-1.7$ & $4.3-1.3$ & $5.0-1.5$ & $\begin{array}{l}34.5- \\
12.0\end{array}$ & $\begin{array}{c}36.8- \\
16.7\end{array}$ & $\begin{array}{c}35.7- \\
14.3\end{array}$ \\
\hline & SEM & 7.61 & 5.43 & 1.74 & 0.86 & 0.52 & 0.45 & 0.73 & 0.45 & 0.21 & 3.30 & 2.41 & 0.87 \\
\hline & $C D$ & 22.82 & 16.28 & 5.74 & 2.59 & 1.55 & NS & 2.20 & 1.36 & 0.70 & 9.89 & 7.21 & 2.88 \\
\hline & CV (\%) & 11.13 & 7.96 & 9.08 & 14.47 & 9.08 & 6.33 & 18.62 & 22.98 & 12.74 & 23.54 & 15.86 & 16.87 \\
\hline$S$ & Germplas & & Lamin & a length $(\mathrm{cm})$ & & & Lamin & th $(\mathrm{cm})$ (Mec & & & t Diameter ( & ) (Mear & \\
\hline $\mathrm{N}$ & $\mathrm{ms}$ & 2014-2015 & & $2015-2016$ & Mean & & $2014-2015$ & 2015-2016 & Mean & 2014-2015 & $2015-2016$ & & ean \\
\hline 1 & BT-162 & 43.8 & & 37.5 & 40.7 & & 11.6 & 11.9 & 11.7 & 6.7 & 7.0 & & 6.9 \\
\hline 2 & BT-183 & 56.8 & & 57.1 & 56.9 & & 12.9 & 13.1 & 13.0 & 9.9 & 10.0 & & 0.0 \\
\hline 1 & MG-01 & 60.3 & & 55.2 & 57.7 & & 14.5 & 14.5 & 14.5 & 8.9 & 8.9 & & 8.9 \\
\hline 2 & MG-05 & 60.1 & & 57.1 & 58.6 & & 14.9 & 15.7 & 15.3 & 7.6 & 7.3 & & 7.5 \\
\hline 3 & MG-06 & 52.6 & & 51.5 & 52.0 & & 12.3 & 11.6 & 12.0 & 7.7 & 7.0 & & 7.4 \\
\hline 4 & MG-07 & 50.5 & & 47.1 & 48.8 & & 12.7 & 13.5 & 13.1 & 8.5 & 10.0 & & 9.3 \\
\hline 5 & MG-4 & 64.8 & & 58.8 & 61.8 & & 17.1 & 17.5 & 17.3 & 10.3 & 10.5 & & 0.4 \\
\hline 6 & MG-8 & 41.3 & & 37.8 & 39.5 & & 11.0 & 12.3 & 11.6 & 5.3 & 6.0 & & 5.7 \\
\hline 7 & MG-9 & 41.9 & & 44.5 & 43.2 & & 12.8 & 12.7 & 12.8 & 5.6 & 6.5 & & 6.0 \\
\hline & Range & $64.8-41.3$ & & $58.8-37.5$ & $61.8-52.0$ & & $17.1-11.0$ & $17.5-11.6$ & 17.3-11.6 & 10.3-5.3 & $10.5-6.0$ & & $4-5.7$ \\
\hline & SEM \pm & 4.29 & & 3.11 & 1.48 & & 1.23 & 0.98 & 0.29 & 0.87 & 0.39 & & .32 \\
\hline & CD (0.05) & 12.87 & & 9.34 & 4.90 & & 3.70 & 2.92 & 0.97 & 2.60 & 1.15 & & .09 \\
\hline & CV $(\%)$ & 14.18 & & 10.87 & 15.10 & & 16.05 & 12.38 & 13.08 & 19.17 & 8.19 & & 2.82 \\
\hline
\end{tabular}

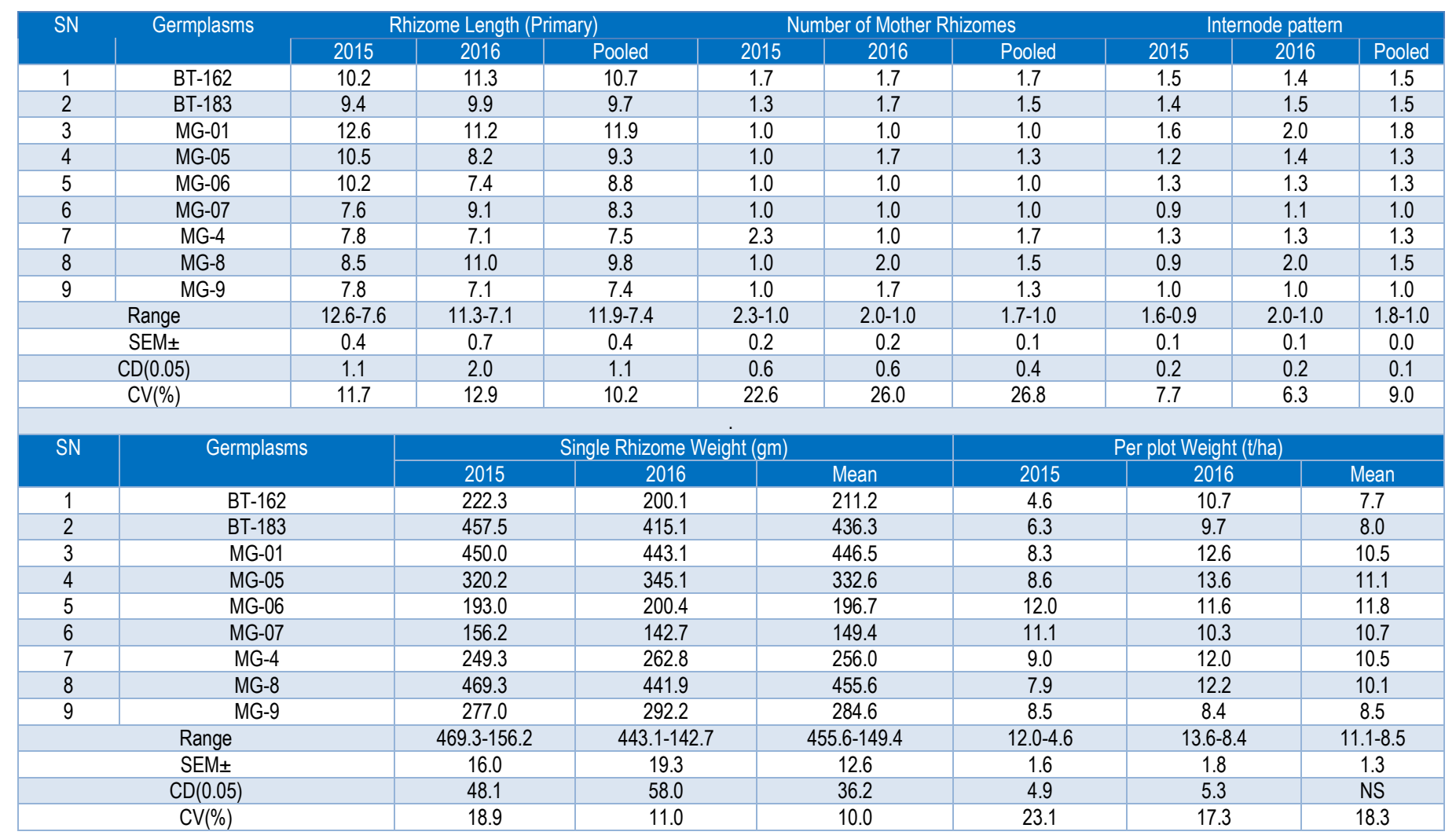

\section{Lamina length}

In the characterization of Lamina length from the pooled data of two years of 9 germplasms, it was found that8numbers of germplasms were found under 'Long' group MG-1, MG-5, MG-6, MG-7, MG-4, MG-9, BT-162 and BT-183 germplasms were found [Table-9]. In 'Medium' group only MG-8 germplasm was found [Table9].

\section{Lamina width}

In the characterization of lamina width from the pooled data of two years of 9 germplasms, it was found that4numbers of germplasms were found in under 'Medium' group MG-5, MG-4, BT-162 and BT-183 [Table-9]. In 'Broad' group MG-1, MG-6, MG-7, MG-9 and MG-8 germplasms were found [Table-9]. 
Table-9 Characterization of Mango ginger and Blue Turmeric plant characters

\begin{tabular}{|c|c|c|c|}
\hline \multicolumn{3}{|c|}{ Plant Height } \\
\hline Short & \multicolumn{2}{c|}{ Tall } \\
\hline & MG-9, MG-8 & \multicolumn{2}{c|}{ MG-1, MG-5, MG-6, MG-7, MG-4, BT-162, BT-183 } \\
\hline \multicolumn{3}{|c|}{ Number of shoots } \\
\hline Few & Many & Medium \\
\hline & BT-162, BT-183 \\
\hline
\end{tabular}

\begin{tabular}{|c|c|c|}
\hline \multicolumn{3}{|c|}{ Number of leaves on main shoot } \\
\hline Few & Inter mediate & Many \\
\hline & MG-5, MG-9, MG-8, BT-183 & MG-1, MG-6, MG-7,MG-4, BT-162 \\
\hline \multicolumn{3}{|c|}{ Petiole length } \\
\hline Short & Inter mediate & Long \\
\hline MG-9 & MG-1, MG-8 & MG-5, MG-4, MG-6, MG-7, BT-162, BT-183 \\
\hline \multicolumn{3}{|c|}{ Lamina length } \\
\hline \multirow[t]{2}{*}{ Short } & Medium & Long \\
\hline & MG-8 & MG-1, MG-5, MG-6, MG-7, MG-4, MG-9, BT-162, BT-183 \\
\hline \multicolumn{3}{|c|}{ Lamina width } \\
\hline \multirow[t]{2}{*}{ Narrow } & Medium & Broad \\
\hline & MG-5, MG-4, BT-162, BT-183 & MG-1, MG-6, MG-7, MG-9, MG-8 \\
\hline
\end{tabular}

\begin{tabular}{|c|c|c|c|c|}
\hline \multicolumn{5}{|c|}{ Leaf venation pattern } \\
\hline \multicolumn{4}{|c|}{ Close } & Distance \\
\hline \multicolumn{4}{|c|}{ MG-1, MG-4, MG-5, MG-6, MG-7, MG-8, MG-9, BT-162, BT-183 } & \\
\hline \multicolumn{5}{|c|}{ Leaf margin } \\
\hline \multirow[t]{2}{*}{ Even } & \multicolumn{4}{|c|}{ Wavy } \\
\hline & \multicolumn{4}{|c|}{ MG-1, MG-4, MG-5, MG-6, MG-7, MG-8, MG-9, BT-162, BT-183 } \\
\hline \multicolumn{5}{|c|}{ Pseudo Stem Habit } \\
\hline \multicolumn{2}{|r|}{ Compact } & & \multicolumn{2}{|l|}{ Open } \\
\hline \multicolumn{2}{|r|}{ MG-5, MG-9 } & \multicolumn{3}{|c|}{ MG-1, MG-6, MG-6, MG-7, MG-4, MG-8, BT-162, BT-183 } \\
\hline \multicolumn{5}{|c|}{ Leaf disposition } \\
\hline \multicolumn{3}{|c|}{ Erect } & Semi-erect & Horizontal \\
\hline \multicolumn{3}{|c|}{ MG-5, MG-9, MG-1, MG-7, MG-4, BT-162 } & MG-6, MG-8, BT-183 & \\
\hline
\end{tabular}

\begin{tabular}{|c|c|c|}
\hline \multicolumn{3}{|c|}{ Rhizome Length } \\
\hline Short & Medium & Long \\
\hline- & \multicolumn{3}{|c|}{ MG-5, MG-6, MG-7, MG-4, MG-8, MG-9, BT-183 BT-162 } \\
\hline \multicolumn{3}{|c|}{ Number of mother rhizomes } \\
\hline One & Tow-Three & More than three \\
\hline \multicolumn{2}{|c|}{ MG-1, MG-6, MG-7 } & Rhizome internode pattern \\
\hline \multicolumn{3}{|c|}{ Distant } \\
\hline Close & MG-5, MG-6, MG-7, MG-4, MG-8, MG-9, MG-1, BT-162, BT-183 \\
\hline- &
\end{tabular}

\begin{tabular}{|c|c|c|c|}
\hline \multicolumn{3}{|c|}{ Status of Tertiary rhizome } & \\
\hline Absent & \multicolumn{3}{|c|}{ Present } \\
\hline \multirow{2}{*}{\multicolumn{4}{|c|}{$\begin{array}{l}\text { MG-5, MG-6, MG-7, MG-8, MG-9, MG-1, BT-162, BT-183 } \\
\text { Rhizome habit }\end{array}$}} \\
\hline & & & \\
\hline Compact & Intermediate & \multicolumn{2}{|c|}{ Rhizome habit } \\
\hline \multirow{2}{*}{\multicolumn{4}{|c|}{$\begin{array}{l}\text { MG-1, MG-6, MG-4, MG-8, MG-9, BT-162, BT-183 } \\
\text { Rhizome Shape }\end{array}$}} \\
\hline & & & \\
\hline \multicolumn{4}{|c|}{ Straight } \\
\hline \multicolumn{3}{|c|}{ MG-7, MG-1, MG-6, MG-4, MG-8, MG-9, BT-162 } & MG-5, BT-183 \\
\hline
\end{tabular}




\section{Leaf margin}

In the characterization of Leaf margin from the pooled data of two years of 9 germplasms, it was found all the germplasms were found under 'Wavy' group MG1, MG-4, MG-5, MG-6, MG-7, MG-8, MG-9, BT-162 and BT-183 [Table-9].

Rhizome habit: In the characterization of rhizome habit from the pooled data of two years of 9 germplasms, it was found that7numbers of germplasms found under 'Loose' group MG-1, MG-6, MG-4, MG-8, MG-9, BT-162 and BT-183 [Table-9]. In 'Intermediate' group MG-5and MG-7 germplasms were found [Table-9].

Rhizome shape: In the characterization of rhizome shape from the pooled data of two years of 9 germplasms, it was found that 7 number of germplasms found under 'Straight' group MG-7, MG-1, MG-6, MG-4, MG-8, MG-9 and BT-162 [Table-9]. In 'Curved' group MG-5 and BT-183 germplasms were found [Table-9].

Rhizome length: In the characterization of rhizome length from the pooled data of two years of 9 germplasms, it was found that7numbers of germplasms found under 'Medium' group MG-5, MG-6, MG-7, MG-4, MG-8, MG-9 and BT183(Table: 4.16.1). In 'Long' group MG-1 and BT-162 germplasms were found [Table-9].

Number of mother rhizome: In the characterization of Number of mother rhizome from the pooled data of two years of 9 germplasms, it was found that6numbers of germplasms found under 'Two-Three' group MG-5, MG-4, MG-8, MG-9, BT-162 and BT-183 [Table-9]. In 'One' group MG-1, MG-6 and MG-7 germplasms were found [Table-9].

Rhizome internode pattern: In the characterization of rhizome internode pattern from the pooled data of two years of 9 germplasms, it was found thatall the 9 germplasms found under 'Distant' group MG-5, MG-6, MG-7, MG-4, MG-8, MG-9, MG-1, BT-162 andBT-183 [Table-9].

Status of Tertiary rhizome: In the characterization of status of tertiary rhizome from the pooled data of two years of 9 germplasms, it was found thatall germplasms were found under 'Present' MG-5, MG-6, MG-7, MG-8, MG-9, MG-1, BT-162 and BT-183 [Table-9].

\section{Conclusion}

In case of plant height, no any germplasm was found under 'Short', 2 germplasms are under 'medium' and 7 germplasms are under 'tall' in this Terai region of West Bengal. In case of number of shoots, no any germplasm was found under 'many', 5 germplasms are under 'medium' and 4 germplasms are under 'few' in this Terai region of West Bengal. In case of number of leaves per plant, 5 germplasms were under the group 'many', 4 were under 'intermediate' and none of the germplasms was under 'few' category in the characterization table. In case of petiole length, 6 germplasm were found under 'long', 2 germplasms were under 'intermediate' and 1 germplasm were under 'short' region of West Bengal. In case of lamina length, 8 germplasms were in under 'long', only 1 germplasm was under 'medium' and no germplasms was in under 'short'. In case of lamina width,2 germplasms were under 'broad', 7 germplasms were under 'medium' and none was under 'narrow'. In case of primary rhizome length, 2 germplasms were under 'long', 7 germplasms under 'medium' and none was under 'short'. In case of number of mother rhizome, 3 germplasms under 'One', 6 germplasms under 'Two-Three' and none was in under 'More Than Three'. In case of, rhizome internode pattern, 1 germplasms were found under 'Close' and 8 germplasms were under 'Distant' group. Overall MG-6 was found to have highest yield per plot, MG-8 was found to have highest rhizome wt, MG-4 was found to have highest number of mother rhizome, MG-1 highest rhizome length in quantitative estimations of rhizome and qualitative estimation was also done for characterization to evaluate the performances of the genotypes in this region.
Application of research: The research is applicable for conservation, characterization and cataloguing of the genetic resources which are very much important process for any type of conservation. Turmeric especially mango turmeric and blue turmeric should be conserved in this way following the characterization process by observation of DUS descriptors.

Research Category: Genetics and Plant Breeding

\section{Abbreviations: \\ MG- Mango ginger (Curcuma amada L) \\ BT- Blue turmeric (Curcuma caesia L)}

Acknowledgement / Funding: Author thankful to ICAR-AICRP on Spices for providing financial support. Author also thankful to Uttar Banga Krishi Vishwavidyalaya, Cooch Behar, 736165, West Bengal, India

\section{${ }^{*}$ Chairperson of research: Dr Soumendra Chakraborty}

University: Uttar Banga Krishi Vishwavidyalaya, Cooch Behar, 736165

Research project name or number: M.Sc. Thesis: Genetic variability analysis, characterization and evaluation of different germplasm of curcuma species in Terai region of West Bengal

\section{Author Contributions: All author equally contributed}

Author statement: All authors read, reviewed, agree and approved the final manuscript

\section{Conflict of Interest: None declared}

Ethical approval: This article does not contain any studies with human participants or animals performed by any of the authors.

\section{References}

[1] Chan E. W. C. (2009) Food Chemistry, 113 (1), 166-172.

[2] Smart J. and Simmonds N. W. (1992) Evolution of Crop Plants. Longman, Edinburgh, 333.

[3] Shamina A., John zachariah T., Sasikumar B. and Johnson George K.(1998) Journal of Horticultural Science \& Biotechnology, 73 (4) 479483.

[4] Peter K. V., Ravindran P.N ., Nirmal Babu K. , Minoo Divakaran (2007) Breeding of Spice Crops (Black Pepper, Cardamom, Ginger and Turmeric).

[5] Ravindran P. N., Babu K. N. and Shiva K. N. (2007) In, Ravindran, P. N., Babu, K N. and Sivaraman K. (eds.) Turmeric, the genus Curcuma, CRC Press, Boca Raton, 16-70.

[6] Hikmat U.J., Rabbani M. A. and Zabta K. S. (2012) Pakistan Journal of Botany, 44, 231-238.

[7] Ravindran P. N., Babu K. N. and Shiva K. N. (2007) In, Ravindran, P. N., Babu, K N. and Sivaraman K. (eds.) Turmeric, the genus Curcuma, CRC Press, Boca Raton, 16-70.

[8] Purseglove L. W., Brown E. G., Green C. and Robin S. R. J. (1981) Turmeric. In, Vol. 2, Longman, New York, 532-580.

[9] Sirirugsa P. (1999) Thai Zingiberaceae. International conference on biodiversity and bioresources, Conservation, utilization. Phuket, Thailand.

[10] Suguira T. (1931) Botanical Magazine Tokyo 45, 353-355

[11] Suguira T. (1936) Cytologia 7, 544-595.

[12] Raghavan T. S., Venkatasubban K. R. (1943) Proceedings of Indian Academy of Sciences Series B, 17, 118-132.

[13] Venkatasubban K. R. (1946. Proceedings of Indian Academy of Sciences Series, B23, 281-300.

[14] Sharma A. K. and Bhattacharyya N. K. (1959) La Cellule, 59, 197-346.

[15] Chakravorti A. K. (1948) Sci. Cul., 14, 137-140. 
[16] Sato D. (1948) Jpn. J. Genet., 23, 44-45.

[17] Das A.B, Rai S., Das P. (1999) Cytobios, 97, 23-33.

[18] Renjith D., Valsala P. A. and Nybe E. V. (2001) J. Spices Arom. Crops, 10, $135-139$.

[19] Nair M. K., Nambiar M. C. and Ratnambal M. J. (1980) 15-23.

[20] Ramachandran K. (1961) Curr. Sci., 30, 194-196.

[21] Ramachandran K. (1969) Cytologia, 34, 213-221.

[22] Nambiar M. C., Pillai P. K. T., Sharma Y. N. (1982) Journal of Plantation Crops, 10, 81-85.

[23] Bavappa A. , Peter K.V., Thomas J., Edison S., Sharma Y. R., Parthasarathy V. A. (2007) Guidelines for the Conduct of Test for Distinctiveness, Uniformity and Stability on turmeric (Curcuma longa L.). Protection of plant varieties and farmers' rights authority (PPV\&FRA) government of India.

[24] Rao A Manohar, Venkar Rao P., Narayana Reddy Y. \& Ganesh M. (2005) Journal of Spices and Aromatic Crops, 14 (2), 165-168.

[25] Bandyopadhyay A., Chattopadhyay N., Ghosh D. and Hore J.K. (2002) Proceedings of placrosym, 15, 471-475.

[26] Nirmal B. K., Sasikumar B., Ratanambal M. J., Joinson G. L. and Windran P. N. R. (1992) Indian Journal of Genetics, 53(1), 91-93.

[27] Padmadevi K., Jeeva Jothi L., Ponnuswami V., Durgavathiand Rijwana V., Rveen I. (2012) The asian journal of horticulture, 7,465467.

[28] Xiao X.H., Zhao Y.L., Cheng J., Su G.M., Fang Q.M. \& Su Z.W.(2004) China Journal of Chinese Materia Medica, 29, 203-207.

[29] Tomar N. S., Nair S. K. and Gupta C. R. (2005) Journal of Spices and Aromatic Crops, 4(1), 75-77.

[30] Singh R.K. \& Chaudhary B.D. (1977) Biometrical Methods in Quantitative Genetic Analysis. Kalyani Publishers, New Delhi .

[31] Sasikumar B. (2005) Plant Genetic Resources, Conservation and Utilization, 3,230-251.

[32] Hazra, P., Roy A. and Bandopadhyay A. (2000) Crop Research, 19 (2), 235-240.

[33] Yadav, R. K., Yadav, S. S., Rai, N., Asati, B. S and Singh, A. K. (2006.) Indian Journal of Horticulture, 63(1),103-106.

[34] Chandra R., Govind S. and Desai A.R. (1999) Journal of Applied Horticulture,1, 142-144.

[35] Sunita K, Singh P. and Kewat R.N. (2014) International Journal of Scientific and Research Publications, 4(8), 220-225.

[36] Dash P.K., Akhtar A. and Mannan M.A. (2014) International Journal of Biosciences, 4, 484-494.

[37] Prajapati K. N., Patel M. A., Patel J. R., Joshi N. R., Patel A. D. and Patel J. R. (2014) Electronic Journal of Plant Breeding, 5(1), 131-137.

[38] Joseph R., Joseph T. and Jose J. (1999) Cytologia 64, 313-317.

[39] Islam M.A. (2004) Genetic diversity of the genus Curcuma in Bangladesh and further biotechnological approaches for in vitro regenerationand long-term conservation of $\mathrm{C}$. longa germplasm. $\mathrm{PhD}$ thesis, University of Hannover, Germany.

[40] Chen Z.Y. and Chen S.J. (1984) Guihaia 4, 13-18.

[41] Sarkar A. K. (1990) Proceedings of Indian Science Congress, 77, 150.

[42] Paisooksantivatana Y. and Thepsen O. (2001) Thai Journal of Agricultural Science, 34, 47-57.

[43] Prana M.S. (1977) Journal of Root Crops, 4, 31-35.

[44] Prana M.S., Sastrapradja S., Hawkes J.G., Lubis I. (1978) Journal of Root Crops, 4, 31-35.

[45] Nayak S., Naik P.K., Acharya L.K., Pattnaik A.K. (2006) Cytologia, 71, 49-55. 